УдК $616.155 .32+615.373(164.222): 616.37-002-08.001 .18$

DOI 10.11603/2414-4533.2017.4.8346

(С В. І. ДЕСЯТЕРИК, М. С. КРИКУН

д3 “Дніпропетровська медична академія МОЗ України”

\title{
Роль лімфоцитів та імуноглобулінів класу G у прогнозуванні розвитку місцевих ускладнень гострого панкреатиту
}

\begin{abstract}
Мета роботи: визначити діагностичну та прогностичну цінність рівня лімфоцитів та імуноглобулінів класу $\mathrm{G}$ для прогнозування розвитку місцевих ускладнень гострого панкреатиту, ризику їх інфікування та необхідності відповідної корекції лікувальної тактики.

Матеріали і методи. Обстежено 30 пацієнтів. Лабораторні та імунологічні дослідження проводили тричі: 1 дослідження при надходженні; 2 дослідження - на 7-му добу; 3 дослідження - перед виписуванням. Проведено імуноферментний аналіз субкласів IgG (G1, G2, G3, G4) в основній групі дослідження. Аналіз на однорідність основної групи та контрольної групи показав, що при розподілі хворих на групи залежно від віку та статі істотних відмінностей не виявлено ( $>>0,05)$, що вказує на їх коректну зіставність та можливість порівняння для виявлення розбіжностей за іншими параметрами.

Результати досліджень та їх обговорення. За даними проведеного ROC-аналізу отримано переконливий доказ щодо здатності прогнозування інтра- та перипанкреатичного скупчення рідини у хворих на гострий панкреатит субкласу імуноглобуліну IgG2. IgG1, IgG3 IgG4 та загальний IgG не мають достатньої прогностичної здатності $(p>0,05)$ і не можуть бути використані у клінічній практиці з даною метою. Площа під ROC кривою для прогностичної здатності IgG2 та рівня лімфоцитів має статистично достовірне значення $(p<0,05)$ та може бути оцінена як середня та добра відповідно. Парне порівняння ROC кривих IgG2 та рівня лімфоцитів між собою показало відсутність суттєвих розбіжностей між ними, отже, у них практично однакові діагностичні можливості. Парне порівняння ROC кривих IgG2 та рівня лімфоцитів стосовно прогнозування необхідності операційних втручань не показало суттєвих розбіжностей між ними та підтвердило найкращі операційні характеристики лімфоцитів.
\end{abstract}

Ключові слова: гострий панкреатит; імуноглобуліни класу G; лімфоцити класу G; ROC-аналіз; ускладнення панкреатиту.

Постановка проблеми і аналіз останніх досліджень та публікацій. До 2012 року класифікація тяжкості панкреатиту та його ускладнень проводили відповідно до прийнятої в Атланті у 1992 р. У 2012 р. Інтернаціональний Консенсус переглянув положення атлантської класифікації [3]. За тяжкістю ГП розподіляють на 3 рівня: легкий, помірної тяжкості та тяжкий [4]. За умов легкого перебігу панкреатиту відсутня ОН, яка визначається за модифікованою шкалою Маршала, та локальні або системні ускладнення. Панкреатит помірної тяжкості характеризується наявністю транзинуючої ОН (тривалістю менше 48 год), локальними ускладненнями та /або загостренням супутньої патології. Тяжкий панкреатит описується як такий, що перебігає за умов персистуючої ОН (>= 48 год) та наявності локальних ускладнень [5]. Враховуючи запуск цитокінового каскаду, велику кількість про- та протизапальних реакцій та клітин, що беруть участь у розвитку відповіді організму при ДП, необхідно розуміти, що частина цих реакцій відбувається за рахунок імунокомпетентних клітин [1]. Під впливом цито- та хемокінів за допомогою нейтрофілів та лімфоцитів на початку захворювання розгортається прозапальна відповідь [2]. Також визначення рівня імуноглобулінів класу G може дати відповідь на запитання щодо потенційної відповіді на імунотерапію, корисну інформацію щодо потенційної відповіді на імунотерапію.
Мета роботи: визначити діагностичну та прогностичну цінність рівня лімфоцитів та імуноглобулінів класу G для прогнозування розвитку місцевих ускладнень гострого панкреатиту, ризику їх інфікування та необхідності відповідної корекції лікувальної тактики.

Матеріали і методи. В умовах міського спеціалізованого відділення з лікування гострого панкреатиту “Міська клінічна лікарня № 8“ ДОР та “Міська клінічна лікарня № 2” ДОР м. Кривого Рогу, які є клінічнимі базами кафедри хірургії, травматології та ортопедії ФПО ДЗ “Дніпропетровська медична академія”, було обстежено 30 пацієнтів. Група контролю - госпіталізовані для проведення планового операційного втручання в задовільному стані (n=10).

Лабораторні та імунологічні дослідження проводили тричі: 1 дослідження - при госпіталізації; 2 дослідження - на 7-му добу; 3 дослідження - перед виписуванням.

Проведено імуноферментний аналіз субкласів IgG (G1, G2, G3, G4) в основній групі дослідження. Вимірювання сироваткової концентрації субкласів IgG здійснювали за допомогою твердофазного імуноферментного аналізу (виробник реактивів Thermo Fisher Scientific Inc., США).

Аналіз на однорідність основної групи та контрольної групи показав, що при розподілі хво- 
рих на групи залежно від віку та статі істотних відмінностей не виявлено ( $p>0,05)$, що вказує на їх коректну зіставність та можливість порівняння для виявлення розбіжностей за іншими параметрами.

Результати досліджень та їх обговорення. Для порівняння інформативності різних субкласів імуноглобулінів $\mathrm{G}$, загального IgG та рівня лімфоцитів у якості прогностичних маркерів діагностики скупчень рідини, інфікування та необхідності операційних втручань при гострому панкреатиті проводили ROC-аналіз.

Ефективність діагностичної здатності оцінювалася за допомогою стандартних операційних характеристик діагностичних моделей: чутливості (Se - sensitivity), специфічності (Sp - specifity), інтегральної характеристики - площі під ROCкривою (area under ROC curve - AUC), яка показує залежність кількості правильно класифікованих випадків до кількості неправильно класифікованих $з 95$ \% довірчим інтервалом (95 \% ДІ). Площа під кривою (AUC) є мірою того, наскільки добре параметр може розрізняти між двома станами. ROC-аналіз та побудова ROC кривих здійснювалася у програмному пакеті MedCalc Version 17.6.
Результати ROC-аналізу наведено у таблиці 1 та на рисунках 1-3.

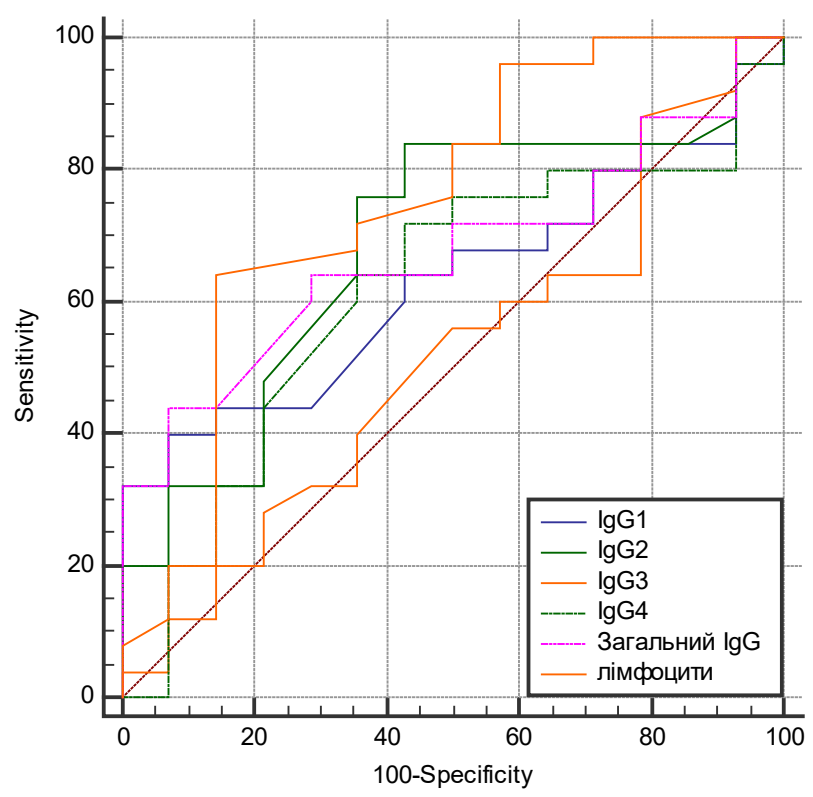

Рис. 1. Порівняння ROC кривих використання імуноглобулінів та рівня лімфоцитів для прогнозу інтрата перипанкреатичних скупчень рідини у хворих на гострий панкреатит.

Таблиця 1. Операційні характеристики ефективності використання імуноглобулінів і рівня лімфоцитів для прогнозу інтра- та перипанкреатичних скупчень рідини, інфікування та необхідності операційних втручань у хворих на гострий панкреатит

\begin{tabular}{|c|c|c|c|c|c|c|}
\hline Показники & IgG1 & $\operatorname{IgG2}$ & IgG3 & IgG4 & Загальний IgG & $\begin{array}{c}\text { Рівень } \\
\text { лімфоцитів }\end{array}$ \\
\hline \multicolumn{7}{|c|}{ Прогнозування інтра- та перипанкреатичних скупчень рідини } \\
\hline Se, $\%$ & 38,46 & 84,62 & 38,46 & 69,23 & 42,31 & 64,00 \\
\hline Sp, \% & 92,86 & 57,14 & 78,57 & 57,14 & 92,86 & 85,71 \\
\hline AUC & 0,604 & 0,685 & 0,504 & 0,604 & 0,651 & 0,751 \\
\hline $95 \%$ ДІ AUC & $0,438-0,755$ & $0,519-0,823$ & $0,342-0,666$ & $0,438-0,755$ & $0,484-0,795$ & $0,587-0,876$ \\
\hline $\mathrm{p}$ & 0,241 & 0,040 & 0,967 & 0,277 & 0,081 & 0,004 \\
\hline \multicolumn{7}{|c|}{ Прогнозування інфікування інтра- та перипанкреатичних скупчень рідини } \\
\hline Se, $\%$ & 33,33 & 88,89 & 100,0 & 44,44 & 33,33 & 100,0 \\
\hline Sp, \% & 90,32 & 54,84 & 29,03 & 80,65 & 87,10 & 70,97 \\
\hline AUC & 0,513 & 0,629 & 0,625 & 0,606 & 0,513 & 0,853 \\
\hline 95 \% ДІ AUC & $0,350-0,674$ & $0,462-0,776$ & $0,458-0,773$ & $0,439-0,756$ & $0,350-0,674$ & $0,703-0,946$ \\
\hline $\mathrm{p}$ & 0,924 & 0,220 & 0,197 & 0,370 & 0,922 & $<0,001$ \\
\hline \multicolumn{7}{|c|}{ Прогнозування необхідності операційних втручань } \\
\hline Se, \% & 43,75 & 93,75 & 93,75 & 43,75 & 37,50 & 80,0 \\
\hline Sp, \% & 70,83 & 54,17 & 25,00 & 79,17 & 79,17 & 79,17 \\
\hline AUC & 0,513 & 0,751 & 0,539 & 0,509 & 0,547 & 0,793 \\
\hline 95 \% ДІ AUC & $0,350-0,674$ & $0,589-0,874$ & $0,375-0,698$ & $0,346-0,670$ & $0,382-0,705$ & $0,633-0,906$ \\
\hline $\mathrm{p}$ & 0,897 & 0,001 & 0,674 & 0,927 & 0,626 & $<0,001$ \\
\hline
\end{tabular}

Примітки: Se - Sensitivity - чутливість; Sp - Specificity - специфічність; AUC - Area Under Curve - площа під ROC-кривою; p - рівень значущості AUC. 


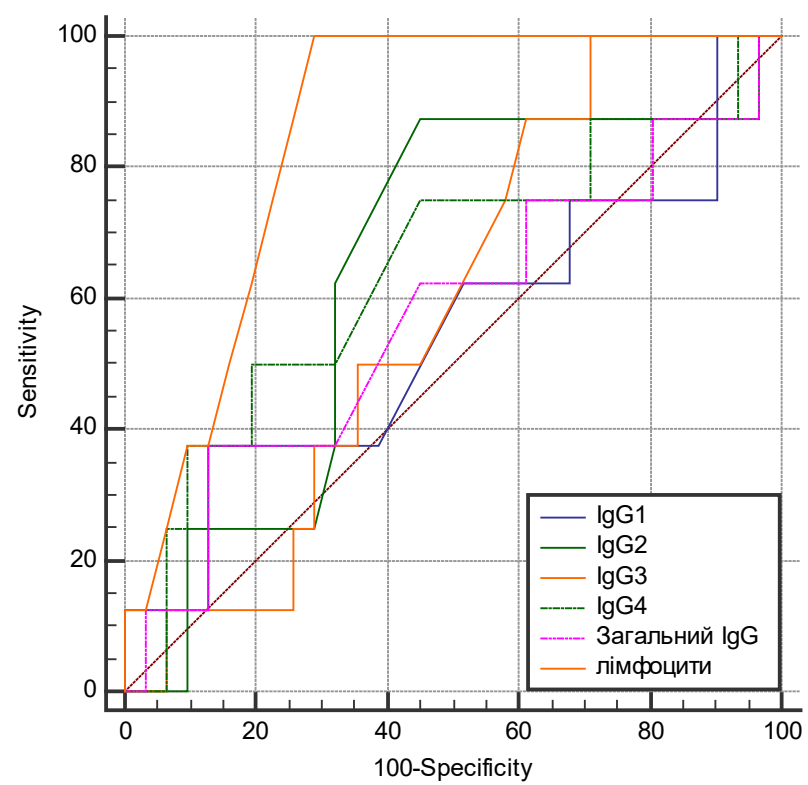

Рис. 2. Порівняння ROC кривих використання імуноглобулінів та рівня лімфоцитів для прогнозу інфікування інтра- та перипанкреатичних скупчень рідини у хворих на гострий панкреатит.

За даними проведеного ROC-аналізу, отримано переконливий доказ щодо здатності прогнозування інтра- та перипанкреатичні скупчення рідини у хворих на гострий панкреатит субкласу імуноглобуліну IgG2, IgG1, IgG3 IgG4 та загальний IgG не мають достатньої прогностичної здатності $(p>0,05)$ і не можуть бути використані у клінічній практиці з даною метою. Площа під ROC кривою для прогностичної здатності IgG2 та рівня лімфоцитів має статистично достовірне значення $(p<0,05)$ та може бути оцінена як середня та добра відповідно. Парне порівняння ROC кривих IgG2 та рівня лімфоцитів між собою показало відсутність суттєвих розбіжностей між ними (різниця між AUC - 0,064; 95 \% ДІ -0,180 - 0,309; $p=0,607$ ), отже, у них практично однакові діагностичні можливості (рис. 1).

Прогнозування інфікування інтра- та перипанкреатичних скупчень рідини з досліджених показників можливо лише на підставі визначення рівня лімфоцитів, для якого отримано статистично значущі результати: AUC=0,853 (95 \% ДІ 0,703 $0,946 ; p<0,001)$, що достовірно перевищує $(p<0,05)$ діагностичні здатності імуноглобулінів $\mathrm{G}$ (рис. 2) та є дуже доброю діагностичною моделлю.

3 проаналізованих показників статистично значущі операційні характеристики щодо прогнозування необхідності операційних втручань виявлено у IgG2 та рівня лімфоцитів - чутливість відповідно 93,75 \% та 80,0 \%; специфічність - 54,17 \% та 79,17 \%; площа рід ROC кривою 3 добрими діагностичними характеристиками AUC $=0,751 \quad(p=0,001)$ та $(\mathrm{AUC}=0,793 ; p<0,001)$

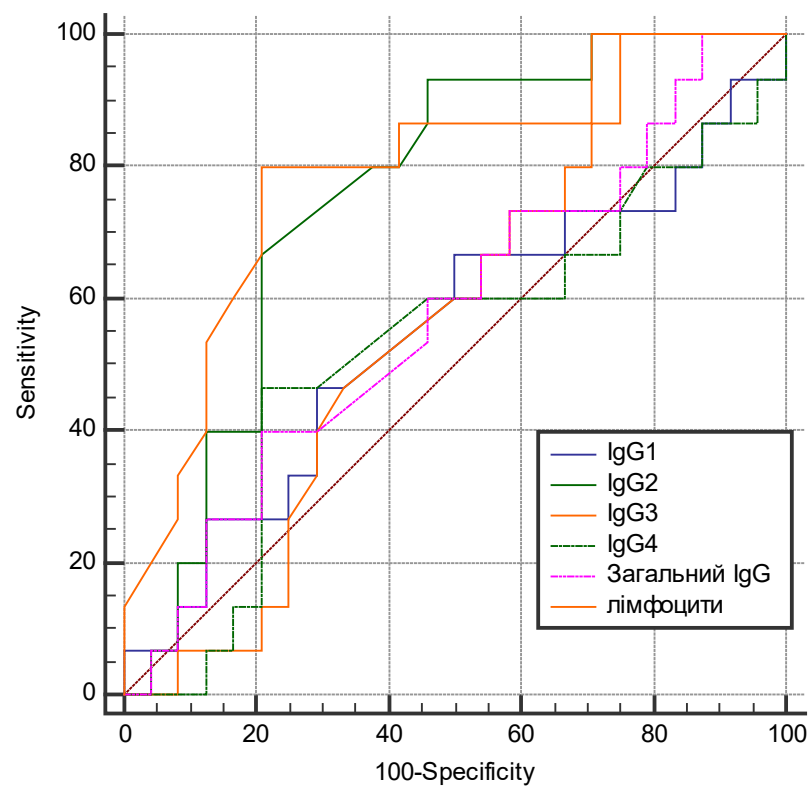

Рис. 3. Порівняння ROC кривих використання імуноглобулінів та рівня лімфоцитів для прогнозу необхідності операційних втручань у хворих на гострий панкреатит.

відповідно. У інших імуноглобулінів $\mathrm{G}$ не виявлено статистичної значущості AUC $(p>0,05)$.

Парне порівняння ROC кривих IgG2 та рівня лімфоцитів стосовно прогнозування необхідності операційних втручань не показало суттєвих розбіжностей між ними (різниця між AUC - 0,033; 95 \% ДІ -0,193 - 0,260; $p=0,773$ ) та підтвердило найкращі операційні характеристики лімфоцитів (рис. 3).

Отже, ROC-аналіз показав статистичні дискримінаційні здатності щодо прогнозу інтра- та перипанкреатичних скупчень рідини, інфікування та необхідності операційних втручань або корекції лікувальної тактики у хворих на гострий панкреатит тільки у високоафінного IgG2, що забезпечує кліренс середовища від антигену та рівня лімфоцитів. Аналіз різниці операційних характеристик вказує на недоцільність використання усіх субкласів жодного з IgG для означених цілей, цілком достатнім $€$ визначення IgG або лімфоцитів.

Висновки. 1. 3 метою прогнозування інтра- та перипанкреатичних скупчень, інфікування та необхідності операційних втручань у хворих на гострий панкреатит ефективно досліджувати тільки IgG2 та рівень лімфоцитів. Ці показники мають однакові діагностичні можливості. 2. 3 метою прогнозування інфікування доцільно використовувати рівень лімфоцитів. 3. В клінічній практиці для прогнозування необхідності операційних втручань достатньо визначення рівня лімфоцитів через відсутність статистичних розбіжностей цього показника та рівня IgG2. 


\section{СПИСОК ЛІТЕРАТУРИ}

1. Jing Li. Immunomodulatory therapies for acute pancreatitis / Li. Jing, Yang Wen-Juan, Huang Lu-Ming, Tang Cheng-Wei // World J. Gastroenterol. - 2014. - No. 7.

2. Marja-L. Inflammation and immunosuppression in severe acute pancreatitis / Marja-L. Kylänpää, Heikki Repo, Pauli Puolakkaine // World J. Gastroenterol. - 2010. - Vol. 16 (23). P. 2867-2872.

3. Classification of acute pancreatitis. 2012: revision of the Atlanta classification and definitions by international consensus /

\section{REFERENCES}

1. Jing, Li, Wen-Juan, Yang, Lu-Ming, Huang, \& Cheng-Wei, Tang (2014). Immunomodulatory therapies for acute pancreatitis. World J. Gastroenterol., 7.

2. Marja-L. Kylänpää, Heikki Repo, \& Pauli Puolakkaine (2010). Inflammation and immunosuppression in severe acute pancreatitis. World J. Gastroenterol., 16 (23), 2867-2872.

3. Banks, P.A., Bollen, Th.L. Dervenis, Chs., Gooszen, H.G.,
P. A. Banks, Th. L. Bollen, Chs. Dervenis [et al.] // Gut. - 2013. - No. 62. - P. 102-111.

4. Sarr M. G. 2012: revision of the Atlanta classification of acute pancreatitis / M. G. Sarr // Pol. Arch. Med. Wewn. - 2013. Vol. 123 (3). - P. 118-124.

5. Sureka B. Imaging lexicon for acute pancreatitis: 2012 Atlanta Classification revisited / B. Sureka, K. Bansal, Y. Patidar, A. Arora // Gastroenterol. Rep. (Oxf). - 2016. - Vol. 4 (1). P. 16-23.
Johnson, C.D., Sarr, M.G. [et al.] (2013). Classification of acute pancreatitis. 2012: revision of the Atlanta classification and definitions by international consensus. Gut,62, 102-111.

4. Sarr, M.G. (2013). 2012: revision of the Atlanta classification of acute pancreatitis. Pol. Arch. Med. Wewn., 123 (3), 118-124. 5. Sureka, B., Bansal, K., Patidar, Y. \& Arora, A. (2016). Imaging lexicon for acute pancreatitis: 2012 Atlanta Classification revisited. Gastroenterol. Rep. (Oxf.), 4 (1), 16-23.

Отримано 11.10.2017

\title{
V. I. DESYATERYK, M. S. KRYKUN
}

Dnipropetrovsk Medical Academy

\section{ABILITY TO DETERMINE THE LEVEL OF LYMPHOCYTES AND IMMUNOGLOBULINS OF CLASS G IN PREDICTING THE DEVELOPMENT OF LOCAL COMPLICATIONS OF ACUTE PANCREATITIS}

\begin{abstract}
The aim of the work: determining the diagnostic and prognostic value of the level of lymphocytes and immunoglobulins of class $\mathrm{G}$ to predict the development of local complications of acute pancreatitis, the risk of their infection and the need for appropriate correction of therapeutic tactics.

Materials and Methods. 30 patients were examined. Laboratory and immunological studies were carried out three times: first research - upon admission; second research - on the $7^{\text {th }}$ day; third research - before discharge. An enzyme-linked immunoglobulin analysis of IgG subclasses (G1, G2, G3, G4) was performed in the main study group. Analysis on the homogeneity of the main group and the control group showed that in the distribution of patients in groups, depending on age and sex, no significant differences were found ( $\mathrm{p}>0.05$ ). which indicates their correctness and comparability for discrepancies in other parameters.

Results and Discussion. According to the ROC analysis, a conclusive proof was made of the ability to predict intra- and peripacreatic fluid accumulation in patients with acute pancreatitis of the subclass of IgG2 immunoglobulin. IgG1, IgG3 IgG4 and total IgG do not have sufficient prognostic ability ( $>>0.05)$ and can not be used in clinical practice for this purpose. The area under the ROC curve for the prognostic ability of IgG2 and the level of lymphocytes has a statistically significant value $(p<0.05)$ and can be estimated as mean and good, respectively. A pair comparison of ROC curves of IgG2 and the level of lymphocytes among themselves showed a lack of significant differences between them, hence they have almost identical diagnostic capabilities. A pair comparison of ROC curves of IgG2 and lymphocyte levels with regard to the prediction of the need for surgical interventions did not reveal significant differences between them and confirmed the best performance characteristics of lymphocytes.

Conclusions. In order to predict intra-and peripancreatic collections, infection and the need for surgical interventions in patients with acute pancreatitis, only IgG2 and lymphocyte levels should be effectively investigated. These indicators have the same diagnostic capabilities. In order to predict infection it is expedient to use the level of lymphocytes. In clinical practice, the prediction of the need for surgical interventions is sufficient to determine the level of lymphocytes due to the lack of statistical differences between this index and the level of IgG2.
\end{abstract}

Key words: acute pancreatitis; immunoglobulins of class G; class G lymphocytes; ROC analysis; complications of pancreatitis. 


\section{В. И. ДЕСЯТЕРИК, М. С. КРИКУН}

гУ “Днепропетровская медицинская академия МЗ Украины”

\section{РОЛЬ .ИМФОЦИТОВ И ИММУНОГЛОБУЛИНОВ К.ЛАСА G В ПРОГНОЗИРОВАНИИ РАЗВИТИЯ МЕСТНЫХ ОС.ОЖНЕНИЙ ОСТРОГО ПАНКРЕАТИТА}

Цель работы: определить диагностическую и прогностическую ценность уровня лимфоцитов и иммуноглобулинов класса $\mathrm{G}$ для прогнозирования развития местных осложнений острого панкреатита, риска их инфицирования и необходимости соответствующей коррекции лечебной тактики.

Материалы и методы. Обследованы 30 пациентов. Лабораторные и иммунологические исследования проводили трижды: 1 исследование - при поступлении; 2 исследования - на 7-е сутки; 3 исследования - перед выпиской. Проведено иммуноферментный анализ субклассов IgG (G1, G2, G3, G4) в основной группе исследования. Анализ на однородность основной группы и контрольной группы показал, что при распределении больных по группам в зависимости от возраста и пола существенных различий не выявлено (р>0,05), что указывает на их корректную сопоставимость и возможность сравнения для выявления расхождений по другим параметрам.

Результаты исследований и их обсуждение. По данным проведенного ROC-анализа получено убедительное доказательство относительно способности прогнозирования интра- и перипанкреатического скопления жидкости у больных с острым панкреатитом субкласса иммуноглобулина IgG2. IgG1, IgG3 IgG4 и общий IgG не имеют достаточной прогностической способности $(\mathrm{p}>0,05)$ и не могут быть использованы в клинической практике с данной целью. Площадь под ROC-кривой для прогностической способности IgG2 и уровня лимфоцитов имеет статистически достоверное значение $(\mathrm{p}<0,05)$ и может быть определена как средняя и хорошая соответственно. Парное сравнение ROC кривых IgG2 и уровня лимфоцитов между собой показало отсутствие существенных различий между ними, так что у них практически одинаковые диагностические возможности. Парное сравнение ROC кривых IgG2 и уровня лимфоцитов в отношении прогнозирования необходимости оперативных вмешательств не показало существенных различий между ними и подтвердило лучшие операционные характеристики лимфоцитов.

Ключевые слова: острый панкреатит; иммуноглобулины класса G; лимфоциты класса G; ROC-анализ; осложнения панкреатита. 